\title{
Helicobacter pylori cagA virulence gene and severe esogastroduodenal diseases: is there an association?
}

\author{
Ana Karoline Silva OLIVEIRA ${ }^{1}$, Lucas Luiz de Lima SILVA', Marina Pacheco MIGUEL ${ }^{2}$, \\ Angel José Vieira BLANCO ${ }^{3}$, Lilian Carla CARNEIRO ${ }^{2}$ and Mônica Santiago BARBOSA ${ }^{1,2}$
}

ABSTRACT - Background - Helicobacter pylori colonizes approximately half of the world's human population. Its presence in the gastric mucosa is associated with an increased risk of gastric adenocarcinoma, gastric lymphoma, and peptic ulcer disease. In Brazil, the high prevalence of $H$. pylori infection is a serious health problem. H. pylori virulence factors are associated with an increased risk of serious gastrointestinal disorders. The $c a g A$ gene encodes a cytotoxin-A-associated antigen (CagA) that is involved in bacterial pathogenicity. H. pylori strains carrying the cag pathogenicity island (cag-PAI) are significantly associated with severe clinical outcomes and histopathological changes. Objective - The present study aims to investigate the prevalence of the $\operatorname{cag} A$ gene among $H$. pylori isolates from patients with different gastric pathologies. Further, the study hopes to verify its association with clinical outcomes. In addition, phylogenetic analysis was performed on $c a g A$-positive $H$. pylori strains from patients with severe and non-severe diseases. Methods - Gastric specimens were collected through a biopsy from 117 patients with different esogastroduodenal diseases. DNA was extracted from these gastric specimens and the polymerase chain reaction was performed to amplify the gene fragments corresponding to the 16S ribosomal RNA and $c a g A$ genes using specific primers. The polymerase chain reaction products of selected samples positive for $c a g A$ were sequenced. The sequences were aligned with reference sequences from the National Center for Biotechnology Information (NCBI) (Bethesda/USA), and a phylogenetic tree was constructed. Results - H. pylori was detected in 65.9\% (77/117) of Brazilian patients with different gastroduodenal disorders. Overall, 80.5\% (62/77) of the strains were $\operatorname{cag} A$-positive. The ages of patients with $\operatorname{cag} A$-positive strains (15 males and 47 females) ranged from 18 to 74 years. The lesions were categorized as non-severe and severe according to the endoscopic and histopathological reports the most prevalent non-severe esogastroduodenal lesion was gastritis $54 / 77(70.12 \%)$, followed by esophagitis $12 / 77(15.58 \%)$ and duodenitis $12 / 77(15.58 \%)$. In contrast, the most prevalent severe lesions were atrophy $7 / 77$ $(9.09 \%)$, followed by metaplasia $3 / 77$ (3.86\%) and gastric adenocarcinoma 2/77 (2.59\%). Phylogenetic analyses performed with the partial sequences of the $\operatorname{cag} A$ gene obtained from local strains were grouped in the same clade. No differences in phylogenetic distribution was detected between severe and non-severe diseases. Conclusion - The cag $A$ gene is highly prevalent among H. pylori isolates from gastric lesions in Brazilian patients. The presence of the $\operatorname{cag} A$ gene was not considered a marker of the severity of esogastroduodenal lesions in the present study. This is the first study to investigate the phylogenetic population structure of $H$. pylori strains in a Brazilian capital, which may improve our understanding of the clinical outcome of $H$. pylori infection.

Keywords - Molecular epidemiology; phylogeny; virulence factors; gene bacterial.

\section{INTRODUCTION}

Helicobacter pylori is a gram-negative bacterium that colonizes the human gastric mucosa ${ }^{(1)}$. It is estimated that approximately half of the world's population is colonized by H. pylori ${ }^{(2)}$. Transmission routes of $H$. pylori are associated with precarious socioeconomic conditions. Therefore, the prevalence of $H$. pylori infection is significantly higher in developing countries ${ }^{(3)}$. In Brazil, the prevalence of infection in some regions is comparable to that of infection rates in Africa, where rates can reach $90^{\%} 0^{(4,5)}$.

$H$. pylori infection favors the development of gastrointestinal diseases, such as gastritis, ulcers, atrophy, lymphoma of the lymphoid tissue of the mucosa (MALT), and gastric adenocarci- noma $(\mathrm{GA})^{(6)}$. Due to its well-established role in carcinogenesis, H. pylori was classified as a Group I carcinogen by the World Health Organization (WHO) in 1994(7). In addition, H. pylori infection is associated with gastroesophageal reflux (GERD). The mechanism underlying $H$. pylori infection-associated GERD is not yet fully understood. Some studies have shown that $H$. pylori-positive patients with arthritis have hypergastrinemia with a consequent decrease in gastric $\mathrm{pH}$. This leads to the worsening of GERD symptoms. However, other studies have reported that the use of proton pump inhibitors in the treatment of $H$. pylori infection can lead to an increase in gastric $\mathrm{pH}$ levels, reducing the symptoms of GERD ${ }^{(8-10)}$.

The development of esogastroduodenal lesions depends on the complex and dynamic relationship between the parasite and the

Declared conflict of interest of all authors: none

Disclosure of funding: no funding received

${ }^{1}$ Universidade Federal de Goiás, Núcleo de Estudos da Helicobacter pylori, Goiânia, GO, Brasil. ${ }^{2}$ Universidade Federal de Goiás, Instituto de Patologia Tropical e Saúde Pública, Goiânia, GO, Brasil. ${ }^{3}$ Instituto Federal de Educação, Ciência e Tecnologia de Goiás - Campus Inhumas, GO, Brasil.

Corresponding author: Mônica Santiago Barbosa. E-mail: santiagosant@gmail.com 
host. This, in turn, is determined by several factors. These include genetic susceptibility of the host, environmental factors, and bacterial virulence ${ }^{(11)}$. The bacterial strains have various virulence genes that influence the pathogenicity of the infection; these include ure $A, \operatorname{ure} B, \operatorname{vac} A, \operatorname{cag} E, \operatorname{sab} A$, ice, and the gene associated with cytotoxin $\mathrm{A}(\operatorname{cag} A)^{(12-14)}$.

The $\operatorname{cag} A$ oncogene, located on the pathogenicity island (cag$\mathrm{PAI})$, encodes the cytotoxin associated with gene $\mathrm{A}(\mathrm{CagA})^{(15,16)}$. The interaction of CagA, with molecules in the gastric epithelium of the host, can increase the severity of esogastroduodenal diseases ${ }^{(17)}$. The bacterium uses the type IV secretion system (T4SS) to inject bacterial factors into the host's intracellular environment ${ }^{(18,19)}$. Once in the intracellular medium, CagA can follow two pathways: independent phosphorylative and dependent phosphorylative.

In the independent phosphorylative pathway, the main cellular changes are interruption of mitogenic signals, changes in cell-cell junctions, and the exacerbation of the activity of inflammatory pathways ${ }^{(15)}$. The dependent phosphorylative pathway occurs when CagA is initially phosphorylated in the EPYIA region (Glu-ProIle-Try-Ala) by the kinases of the SCR and Abl family, followed by binding to the SH2 domain of SHP-2 phosphatase ${ }^{(16,20)}$. The formation of the CagA-SHP-2 complex causes abnormal cell events. These include the dysregulation of cell growth, changes in the cytoskeleton, increased proliferation and mobility, changes in cell junctions, and the expression of pro-inflammatory, pro-mitogenic, and pro-apoptotic proteins ${ }^{(12)}$.

$\operatorname{cag} A$ is one of the most characterized virulence genes as severe esogastroduodenal lesions, such as GA, are frequently associated with $\operatorname{cag} A$-positive $H$. pylori strains $^{(21,22)}$. Although some studies have demonstrated the association of this gene with severe esogastroduodenal diseases, there is still a lack of information regarding the Brazilian population. The aim of this study was to investigate the prevalence of $\operatorname{cag} A$ in dyspeptic patients, as well as the association of the oncogene with the severity of different esogastroduodenal lesions. In addition, the present study evaluated the phylogenetic relationship of cagA-positive $H$. pylori strains isolated from patients with severe and non-severe diseases.

\section{METHODS}

\section{Ethical considerations}

The study protocol was reviewed and approved by the Research Ethics Committee of the Federal University of Goias (CEP/UFG). The study was conducted in accordance with the Ethical Standards of the Brazilian National Committee of Ethics in Human Research, which follows the principles of the Declaration of Helsinki. The approval number is: 2.519.032 (CAAE: 83422017.7.0000.5078). Informed consent was obtained from all the participants.

\section{Study participants}

The study was conducted in Goiânia, State of Goiás, Central West Brazil. Both male and female participants and those aged 18 years and older who agreed to participate in the study were recruited from a referral center for gastric diseases. Participants were excluded from the study if they used antibiotics and immunosuppressants eight weeks prior to sample collection, the use of proton pump inhibitors two weeks prior to sample collection, gestation, lactation, active gastrointestinal bleeding, and a history of gastrectomy. The participants were recruited from January to December 2018. A total of 117 participants were included in the study.

\section{Samples}

After clinical evaluation, the participants underwent endoscopy, which was performed by a trained endoscopist. Macroscopic data included topography, localization, and type of injury. During the procedure, gastric biopsies were carried out (two in the antrum, two in the body) in accordance with the recommendations of the IV Consensus on Helicobacter pylori infection ${ }^{(23)}$. The samples were sent to the clinical pathology laboratory of the University hospital for histopathological analysis and to the Nucleus for the Study of Helicobacter pylori at the Federal University of Goiás (NEHP/ UFG) for molecular analysis.

\section{Histopathological analysis}

Histopathological examination was performed at the pathology laboratory of the reference hospital. All clinical specimens were fixed in $10 \%$ formaldehyde and stained with hematoxylin-eosin and Giemsa stain ${ }^{(24)}$. The gastric mucosa was assessed according to the Sydney system ${ }^{(25)}$.

\section{Esogastroduodenal injuries and severity criteria}

Endoscopic and histopathological reports were used to segregate patients with severe and non-severe esophagogastroduodenal lesions. According to the recommendations of Paredes-Osses et al., $2017^{(26)}$ and Bellolio et al., 2019(27), injuries categorized as severe were GA, gastric atrophy, intestinal and non-severe metaplasia, esophagitis, duodenitis, gastritis, and ulcers.

\section{DNA extraction and genotyping of $\boldsymbol{H}$. pylori}

Molecular analysis was carried out at the Nucleus for the Study of Helicobacter pylori at the Federal University of Goiás (NEHP/ UFG). The clinical specimens were subjected to DNA extraction using the commercial kit KitQIamp DNA Minikit ${ }^{\circledR}$ (Qiagen, Valencia, CA, USA), according to the manufacturer's instructions. The DNA concentration was determined using NanoDrop ${ }^{\circledR}$ (ND1000 UV-Vis).

H. pylori was detected by polymerase chain reaction (PCR) using the ribosomal $16 \mathrm{~S}$ rRNA gene as described previously by Luscenti and Gatti, 2008(28). Positive samples for the 16S rRNA gene were subjected to amplification of the $\operatorname{cag} A$ virulence gene by PCR as described by Dadashzadeh et al., 2017 ${ }^{(29)}$. The primer sequences, reaction conditions, and sizes of the amplified fragments are listed in TABLE 1.

The PCR products were stained with Blue Green Loading Dye I (LGC Biotecnologia, São Paulo, Brazil) and then subjected to electrophoresis on $2 \%$ agarose gel. The product was visualized under ultraviolet light and the images were documented.

\section{Sequencing and phylogenetic analysis of the cagA gene}

Sequencing was performed according to the method proposed by Sanger et al., 1978 ${ }^{(30)}$, using the DYEnamicTM ET Terminator Cycle Sequencing Kit (GE Healthcare, USA) and ABI Prism 3100 (Applied Biosystems). Phylogenetic analyses were performed using the Molecular Evolutionary Genetics Analysis Software (MEGA), version $10.1^{(31)}$. The phylogenetic tree was constructed using the maximum parsimony method with 1000 bootstraps considering the gaps generated in the alignment as a fifth base.

\section{Data analysis}

Statistical analyses was performed using the GraphPad Prism version 7.0, and SAS version 9.1 packages. The probability of se- 
TABLE 1 . Sequence of primers, reaction conditions and sizes of amplified fragments of the 16S rRNA and cagA genes.

\begin{tabular}{|c|c|c|c|c|c|}
\hline \multirow{2}{*}{ Gene } & \multirow{2}{*}{ Primer } & \multirow{2}{*}{ Primer sequence } & Amplification & \multirow{2}{*}{ bp } & \multirow{2}{*}{ Reference } \\
\hline & & & Conditions & & \\
\hline \multirow{2}{*}{$\begin{array}{l}16 \mathrm{~S} \\
\text { rRNA }\end{array}$} & $b p \times 1$ & CTGGAGARACTAAGYCCTCC & $94^{\circ} \mathrm{C} 5^{\prime}, 40$ cycles $94^{\circ} \mathrm{C} 1^{\prime}$ & \multirow{2}{*}{150} & \multirow{2}{*}{$\begin{array}{l}\text { Lusceti and Gatti, } \\
2008\end{array}$} \\
\hline & $b p \times 2$ & GAGGAATACTCATTGCGAAGGCGA & $59^{\circ} \mathrm{C} 1^{\prime} / 72^{\circ} \mathrm{C} 1^{\prime}$ and $72^{\circ} \mathrm{C} 7^{\prime}$. & & \\
\hline \multirow{2}{*}{$\operatorname{cag} A$} & cag1 & ATGACTAACGAAACTATT & $94^{\circ} \mathrm{C} 5^{\prime}, 25$ cycles $94^{\circ} \mathrm{C} 1^{\prime}$ & \multirow{2}{*}{232} & \multirow{2}{*}{$\begin{array}{c}\text { Dadashzadeh et al., } \\
2017\end{array}$} \\
\hline & $\operatorname{cag} 2$ & CAGGATTTTTGATCGCTTTATT & $53^{\circ} \mathrm{C} 1^{\prime} / 72^{\circ} \mathrm{C} 1^{\prime}$ and $71^{\circ} \mathrm{C} 7^{\prime}$. & & \\
\hline
\end{tabular}

verity, as well as its association with the $\operatorname{cag} A$ gene, was estimated using odds ratios (ORs). Fisher's exact test was used to analyze the sex and severity. The relationship between age and severity was evaluated using two-way ANOVA with Tukey's post-hoc test. Data will be presented as mean and standard deviation (mean \pm standard deviation). The results were considered statistically significant in case of $P<0.05$, with a $95 \%$ confidence interval (CI).

\section{RESULTS}

DNA extracted from gastric biopsies was used for molecular screening of the bacteria by amplifying the $16 \mathrm{~S}$ rRNA gene. Samples that amplified a $150 \mathrm{bp}$ fragment were considered positive (FIGURE 1A). H. pylori-positive samples were used to amplify a $232 \mathrm{bp}$ fragment of the $\operatorname{cag} A$ virulence gene (FIGURE 1B).

H. pylori was detected in $65.9 \%(77 / 117)$ of samples from gastric specimens. Among $H$. pylori-positive samples, 80.5\% (62/77) were $\operatorname{cag} A$-positive and $19.5 \%$ (15/77) were cagA-negative. $H$. pyloripositive patients were segregated into two groups based on the type of lesion (non-severe and severe).

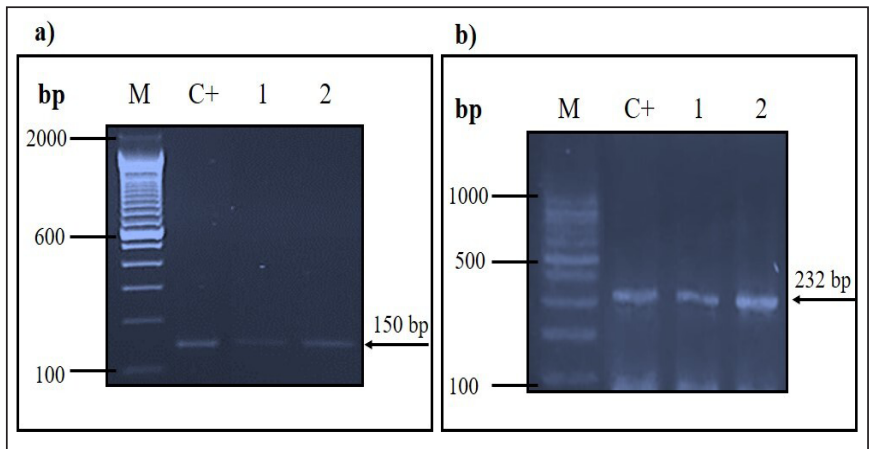

FIGURE 1. Amplification products of the $H$. pylori $16 \mathrm{~S}$ rRNA and cag $A$ genes. M: molecular weight labeled (1a. 2000 bp / 1b. 1000 bp); C +: positive control; (a) lanes 1 and 2: 16S rRNA gene amplification product (150 bp amplicon); (b) lanes 1 and 2: cagA gene amplification product (232 bp amplicon).

A total of 90 clinical outcomes were detected, 78 of which were non-severe and 12 were severe. Since the same patient could have more than one esogastroduodenal lesion, the number of clinical outcomes was higher than the number of patients in the study. The most prevalent non-severe esogastroduodenal lesion was gastritis $54 / 77(70.12 \%)$, followed by esophagitis $12 / 77(15.58 \%)$ and duodenitis $12 / 77(15.58 \%)$. In contrast, the most prevalent severe lesions were atrophy $7 / 77(9.09 \%)$, followed by metaplasia $3 / 77(3.86 \%)$ and GA 2/77 (2.59\%).

Gastric biopsy samples from cagA-positive $H$. pylori patients with severe and non-severe lesions were used for photomicrography, as shown in FIGURE 2. Photomicrographs $2 \mathrm{a}$ and $2 \mathrm{~b}$ show severe lesions in the gastric tissues of patients with atrophy and GA, respectively. FIGURES $2 \mathrm{c}$ and $2 \mathrm{~d}$ show gastritis and duodenitis, respectively, considered non-severe lesions.

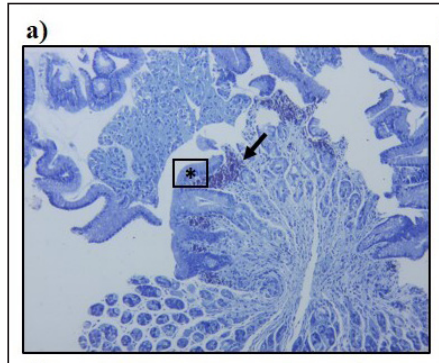

c)
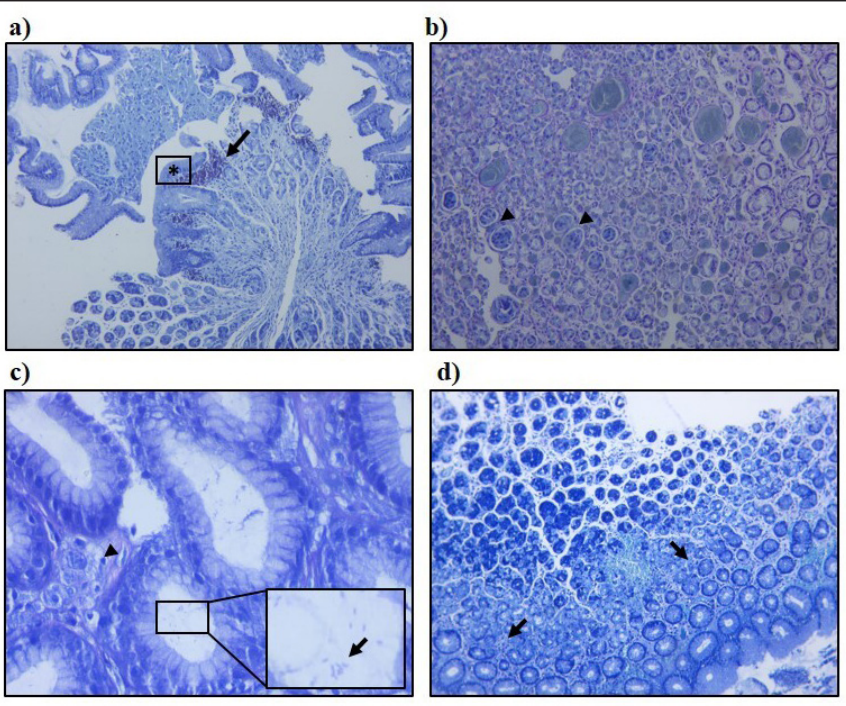

FIGURE 2. Photomicrograph of gastric tissue lesions in patients infected with positive $H$. pylori cagA strains. (a) Atrophy in the gastric mucosa (*) and multifocal inflammatory infiltrate in the submucosa (arrow). 10x. Giemsa. (b) GA - it is possible to observe proliferation of tubular structures containing cells with atypical cells and evidence of malignancy (arrowhead). 10x. Giemsa. (c) Gastritis, discrete inflammatory aggregates (arrowhead), and the presence of H. pylori (arrow) are observed. 10x. Giemsa (d) Duodenitis - it is possible to observe multifocal inflammatory infiltrate (arrow). 10x. Giemsa.

The analysis of the association between the 90 clinical outcomes found 78 non-severe cases and 12 severe cases. In addition, it found the presence of $\operatorname{cag} A$ was performed to assess the role of this gene in the severity of esogastroduodenal diseases. The results showed that there was no statistically significant association between $\operatorname{cag} A$ and lesion severity $(\mathrm{OR}=0.90, \mathrm{CI}$ : 0.2200-3.6821, $P=0.8835)$ (TABLE 2).

Clinical outcomes were also analyzed individually to assess whether the $\operatorname{cag} A$ gene was specifically associated with the severity of esogastroduodenal lesions. The odds ratios, confidence intervals, and $P$-values, are listed in TABLE 3 . Additionally, we evaluated whether the $\operatorname{cag} A$ gene acted as a risk or protection factor in the development of specific gastropathy. Statistical analyses did not show an association between $\operatorname{cag} A$ and the various isolated clinical outcomes (TABLE 3). 
TABLE 2. Relationship between the presence of $\operatorname{cag} A$ and the severity of esogastroduodenal injuries.

\begin{tabular}{|c|c|c|c|c|c|}
\hline & $\begin{array}{c}\text { Non-severe } \\
\text { diseases } \\
(n=78)\end{array}$ & $\begin{array}{c}\text { Severe } \\
\text { diseases } \\
(\mathrm{n}=12)\end{array}$ & OR & CI $95 \%$ & $P$ \\
\hline $\begin{array}{l}\text { cagA+ } \\
(\mathrm{n}=62)\end{array}$ & $\begin{array}{c}60 \\
(76.92 \%)\end{array}$ & $\begin{array}{c}9 \\
(75.00 \%)\end{array}$ & \multirow{2}{*}{0.90} & \multirow{2}{*}{$0.2200-3.6821$} & \multirow{2}{*}{0.8835} \\
\hline $\begin{array}{l}\operatorname{cag} A- \\
(\mathrm{n}=15)\end{array}$ & $\begin{array}{c}18 \\
(23.08 \%)\end{array}$ & $\begin{array}{c}3 \\
(25.00 \%)\end{array}$ & & & \\
\hline
\end{tabular}

OR: odds ratio, was used for statistical analysis.

TABLE 3. Relationship between clinical outcomes* and the H. pylori cagA virulence gene.

\begin{tabular}{lccccc}
\hline \multicolumn{6}{c}{ Non-severe diseases } \\
\hline cagA & Disease & OR & CI 95\% & $\boldsymbol{P}$ \\
\hline \multicolumn{6}{c}{ Gastritis } \\
No (n=23) & Yes $(\mathrm{n}=54)$ & & & \\
cagA+ & $20(86.96 \%)$ & $42(77.78 \%)$ & & & \\
cagA- & $3(13.04 \%)$ & $12(22.22 \%)$ & 0.5250 & $0.1331-$ & 0.3575 \\
& & & & &
\end{tabular}

\section{Esophagitis}

No $(\mathrm{n}=65) \quad$ Yes $(\mathrm{n}=12)$

$\mathrm{cag} \mathrm{A}+\quad 53(81.54 \%) \quad 9(75.00 \%)$

cagA- $12(18.46 \%) \quad 3(25.00 \%)$

$0.6792 \quad 0.1595-$

$2.8932-0.6009$

\section{Duodenitis}

\begin{tabular}{|c|c|c|c|c|c|}
\hline & No $(n=65)$ & Yes $(n=12)$ & & & \\
\hline $\operatorname{cag} \mathrm{A}+$ & $53(81.54 \%)$ & $9(75.00 \%)$ & \multirow{2}{*}{0.6792} & \multirow{2}{*}{$\begin{array}{c}0.1595- \\
2.8932\end{array}$} & \multirow{2}{*}{0.6009} \\
\hline $\operatorname{cag} A-$ & $12(18.46 \%)$ & $3(25.00 \%)$ & & & \\
\hline
\end{tabular}

Severe diseases

\begin{tabular}{cccccc} 
cagA & \multicolumn{2}{c}{ Disease } & OR & CI 95\% & $P$ \\
& Atrophy & & & \\
& No $(\mathrm{n}=70)$ & Yes $(\mathrm{n}=7)$ & & & \\
cagA+ & $57(81.43 \%)$ & $5(71.43 \%)$ & & & \\
cagA- & $13(18.57 \%)$ & $2(28.7 \%)$ & 0.5702 & $0.0994-$ & 0.5285
\end{tabular}

Metaplasia

$\begin{array}{cccccc}\text { No }(\mathrm{n}=74) & \text { Yes }(\mathrm{n}=3) & & & \\ \mathrm{cagA}+ & 60(81.08 \%) & 2(66.67 \%) & & & \\ \text { cagA- } & 14(18.92 \%) & 1(33.33 \%) & & 5.56395- & 0.5453\end{array}$

Gastric adenocarcinoma

$$
\text { No }(\mathrm{n}=75) \quad \text { Yes }(\mathrm{n}=2)
$$

cagA $+\quad 60(80.00 \%) \quad 2(100.00 \%)$

\begin{tabular}{cccccc} 
cagA- $\quad 15(20.00 \%)$ & $0(0.00 \%)$ & 1.281 & $\begin{array}{l}0.0584- \\
28.0755\end{array}$ & 0.8751 \\
\hline OR: odds ratio, was used for statistical analysis. *Clinical outcomes were detected by endoscopic
\end{tabular} and histopathological reports.
The relationship between severity and sex showed that in severe esogastroduodenal lesions, $18.8 \%$ of female patients were infected with $\operatorname{cag} A$-negative $H$. pylori strains and $10.6 \%$ were infected with cag $A$-positive $H$. pylori strains (18.18 \pm 11.62 vs $10.63 \pm 4.49)$. In male patients with severe diseases, $25 \%$ were infected with $\operatorname{cag} A$-negative $H$. pylori strains and $20 \%$ were infected with $\operatorname{cag} A$-positive $H$. pylori strains (25.0 \pm 21.65 vs $20.0 \pm 10.32)$. No statistically significant differences were observed between the groups (FIGURE 3 ).

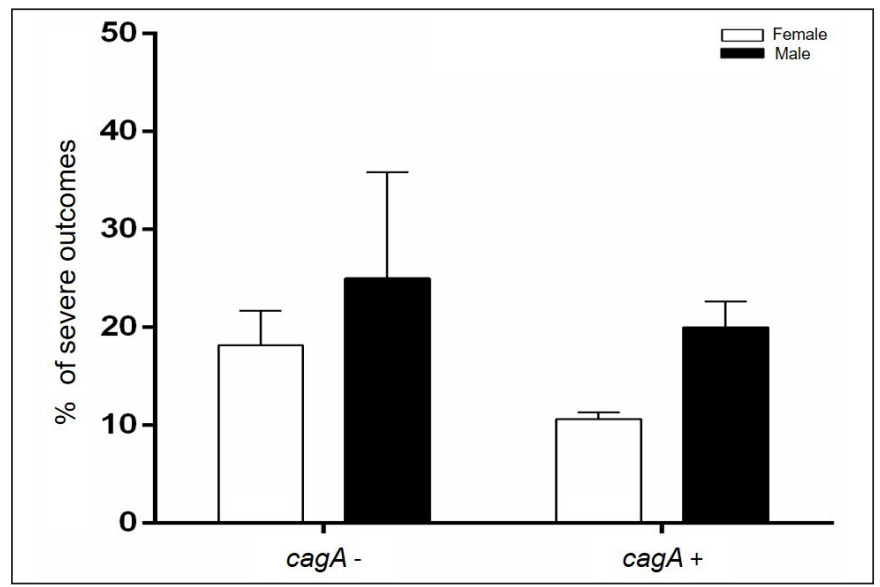

FIGURE 3. Role of the $\operatorname{cag} A$ gene in the severity of disease outcome according to sex. Black bars, male; white bars, female. Test used: Fisher's exact test.

The age of the evaluated patients ranged between 18 and 71 years; the average age was 44.4 years. The analysis of the age groups of patients with non-severe esogastroduodenal injuries with $\operatorname{cag} A$ positive and $\operatorname{cag} A$-negative gastric specimens showed that there was no statistically significant association in the non-severe injury group (mean $\pm \mathrm{SD} ; 14.28 \pm 13.43$ ). In patients with severe injuries, no statistically significant association was found between the oncogene and the age group (mean $\pm \mathrm{SD} ; 15.08 \pm 18.53$ ) (FIGURE 4).

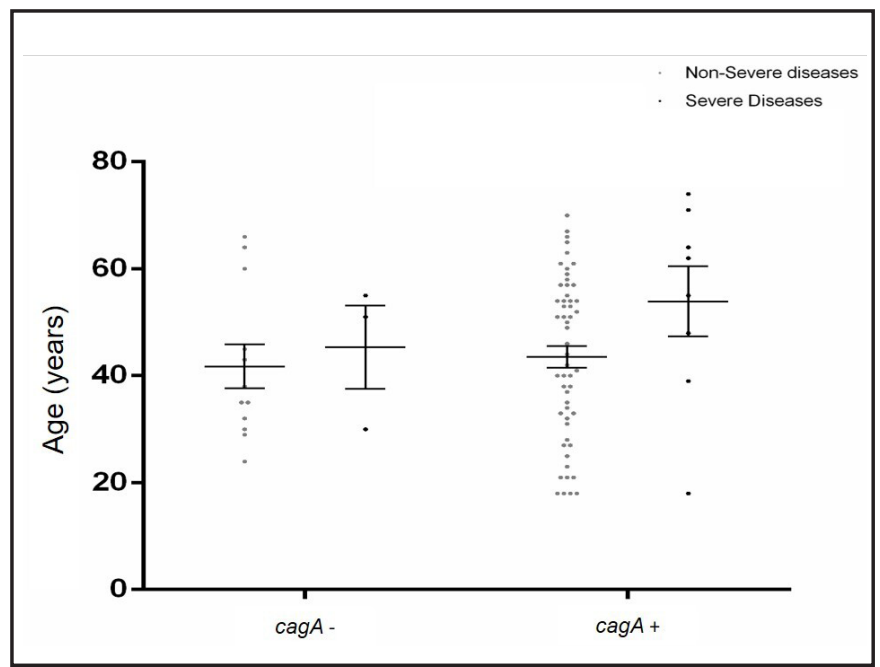

FIGURE 4. Evaluation of possible association between the cagA oncogene and the severity of esogastroduodenal lesions according to the age group of the patients. Circles filled in black: severe disease; circles filled in gray: non-severe disease. The two-way ANOVA test with Tukey's post-hoc test was used for statistical analysis. 
The phylogenetic tree was constructed from the alignment of 16 $\operatorname{cag} A$ sequences from local strains in the present study; 20 reference sequences obtained from the NCBI GenBank (http://www.ncbi. nlm.nih.gov/Genbank/). The sequences used in the construction of the phylogenetic tree were obtained from $H$. pylori strains isolated from patients with severe and non-severe esogastroduodenal lesions.

Phylogenetic analysis showed that local strains were similar. In addition, it was observed that sequences obtained from patients five and six showed a strong genetic association between them and most of the reference sequences. $H$. pylori strains from patients with severe and non-severe pathologies were scattered in the phylogenetic tree. Moreover, our study did not detect any difference in the phylogenetic distribution between severe and non-severe diseases (FIGURE 5).

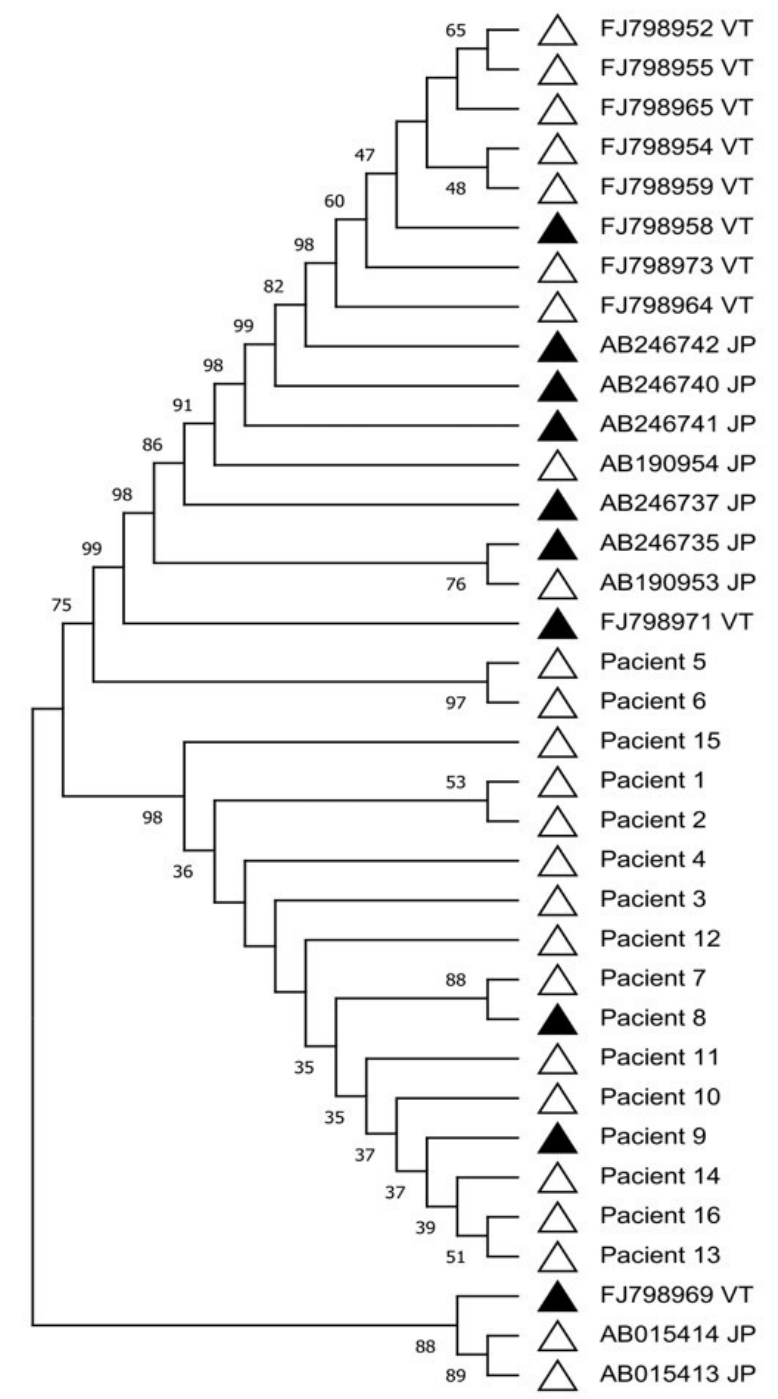

FIGURE 5. Phylogenetic tree constructed with sequences of the $H$. pylori cagA gene. Triangles filled in white represent non-severe strains; black triangles represent severe strains. Neighbor joining was built on MEGA 5.0 , using maximum parsimony and 1000 repetition bootstraps, based on the 16 local cag $A$ sequences and another 10 reference sequences obtained from the GenBank database.

\section{DISCUSSION}

$H$. pylori is an oncobacterium widely recognized globally and it is estimated that approximately half of the world's population is infected by it ${ }^{(2)}$. Different genotypes of $H$. pylori produce different virulence factors. Our study focused on the characterization of the $H$. pylori cag $A$ virulence gene from gastric biopsy samples which were obtained from patients with diseases of the upper gastrointestinal tract and its relationship with clinical status.

The presence of the $\operatorname{cag} A$ oncogene is extremely important for the establishment of severe and non-severe esogastroduodenal lesions. In the present study, the $\operatorname{cag} A$ gene was detected in $80.5 \%$ $(62 / 77)$ of the patients infected with $H$. pylori. This infection rate is considered high compared to other regions of the world. Our results are similar to those of studies conducted in Iran, Greece, and Bulgaria which showed detection rates of $70.0 \%, 73.0 \%$, and $83.0 \%$ respectively ${ }^{(32)}$. On the other hand, some countries showed lower rates of $\operatorname{cag} A$ detection. These included Chile (15.2\%) and Malaysia $(43.0 \%)^{(24,33)}$. The different rate of detection of the $\operatorname{cag} A$ gene can possibly be attributed to the genetic polymorphism, characteristics of different $H$. pylori strains, as well as the different rates of prevalence of infection in these countries ${ }^{(34)}$.

Several severe and non-severe clinical outcomes were associated with the presence of $\operatorname{cag} A$-positive $H$. pylori strains. The association between severity and the oncogene may be due to factors such as the genetic profile of the strains circulating in the region, the sample size of the study, and variations in socioeconomic conditions ${ }^{(24,35)}$. In the present study, a comparison was made between the different clinical outcomes (severe and non-severe) in patients infected with $H$. pylori $\operatorname{cag} A$-positive strains. There was no statistical difference between the presence of the gene and the severity of esogastroduodenal lesions in the study population. Similar results were found in Chile where research showed that there was no association between the gene and the severity of esogastroduodenal lesions ${ }^{(24)}$. In contrast, studies conducted in the Brazilian population by Ramis et al., 2010 ${ }^{(36)}$ demonstrated a relationship between $\operatorname{cag} A$ and severe diseases.

In the present study, the most prevalent severe and non-severe injuries were atrophy and gastritis, respectively. Similar results were found in a study by Cavalcante et al. $2012^{(37)}$ where gastritis was the most prevalent non-severe injury. In contrast, in the study by Oliveira et al. 2003 ${ }^{(38)}$ - carried out in South-West Brazil - showed that one of the most prevalent severe injury was gastric cancer. The individual evaluation of several clinical outcomes associated with the $\operatorname{cag} A$ gene did not demonstrate statistical significance.

To assess the association of the $\operatorname{cag} A$ gene with the severity of gastric diseases in different countries, a bibliographic survey of global gastric cancer incidence rates was carried out in both sexes and all ages which was standardized by age estimated in 2018 (agestandardised incidence rates, ASIR). The levels of gastric cancer risk were segregated according to the geographical location, in low, medium, and high categories, as per the International Agency for Research on Cancer (IARC) recommendations ${ }^{(39)}$. As shown in TABLE 4, we observed that in several regions (with a high incidence of gastric cancer), the $\operatorname{cag} A$ gene was not associated with severity corroborating our data.

The photomicrographs from the present study showed histopathological patterns of severe (atrophy and GA) and non-severe (gastritis and duodenitis) lesions. The mechanisms involved in the genesis of esogastroduodenal diseases associated with $H$. pylori infection have not yet been fully elucidated. However, it is well understood 
TABLE 4. Association of the cagA gene with the risk of severe diseases in areas of low, moderate, or high risk of gastric cancer.

\begin{tabular}{|c|c|c|c|c|}
\hline Continents & Countries & ASIR in both sexes (2018) & $\operatorname{cag} A$ severity-related & References \\
\hline \multirow{6}{*}{ Africa } & South Africa & 4.0 & No & Tanih NF, et al. 2010 \\
\hline & Egypt & 2.8 & No & El-Khlousy M, et al. 2016 \\
\hline & Gambia & 1.4 & Yes & Secka O, et al. 2011 \\
\hline & Ghana & 5.7 & Yes & Archampong TN, et al. 2017 \\
\hline & Morocco & 4.7 & No & Boukhris AS, et al. 2012 \\
\hline & Senegal & 6.8 & Yes & Breurec S, et al. 2012 \\
\hline \multirow{5}{*}{ Asia } & Iran & 15.8 & Yes & Bakhti SZ, et al. 2020 \\
\hline & Bangladesh & 5.2 & No & Aftab H, et al. 2017 \\
\hline & China & 20.7 & No & Pinto-Ribeiro I, et al. 2016 \\
\hline & South Korea & 39.6 & Yes & Boonyanugomol W, et al. 2020 \\
\hline & India & 4.5 & No & Jeyamani L, et al. 2018 \\
\hline \multirow{7}{*}{ Latin America } & Brazil & 7.9 & Yes & Cavalcante MQF, et al. 2012 \\
\hline & Brazil & 7.9 & Yes & Vinagre RMDF, et al. 2013 \\
\hline & Brazil & 7.9 & No & Gatti LL, et al. 2005 \\
\hline & Chile & 17.8 & No & Paredes-Osses E, et al. 2017 \\
\hline & Colombia & 12.8 & Yes & Watada M, et al. 2011 \\
\hline & Costa Rica & 13.4 & Yes & Molina-Castro S, et al. 2019 \\
\hline & Cuba & 5.7 & No & Feliciano O, et al. 2015 \\
\hline North America & United States & 4.1 & No & Homan M, et al. 2014 \\
\hline \multirow{2}{*}{ Europe } & Portugal & 11.0 & Yes & Almeida N, et al. 2014 \\
\hline & Russia & 13.3 & No & Momynaliev K, et al. 2003 \\
\hline
\end{tabular}

Age-standardised incidence rates were obtained from GLOBOCAN 2018 (http://gco.iarc.fr/today).

that the presence of the bacterium in the gastric mucosa can cause changes in gastric homeostasis ${ }^{(38)}$. In addition, from phosphorylative and non-phosphorylative pathways, the CagA oncoprotein can induce exacerbated inflammation and GA induction ${ }^{(40)}$.

The prevalence of infection in patients with $\operatorname{cag} A$-positive $H$. pylori strains may vary according to the sex of the individual. Studies have shown that these variations may be due to differences in lifestyle between men and women ${ }^{(4)}$. In the present study, the relationship between the sex of patients and the severity of esogastroduodenal diseases was evaluated. No statistical significance was observed in patients of both sexes. The proportion of female patients in the present study was almost three times higher than that of males. This can be explained by the greater demand for women by basic health services facilitating early detection and effective treatment ${ }^{(41-44)}$.
Through phylogenetic evaluation, it was not possible to segregate the $\operatorname{cag} A$ sequences isolated from patients with severe and non-severe esogastroduodenal diseases. In part, this can be explained by partial sequencing of the virulence gene, which was used in the analysis.

The similarity between the sequences of patients five and six suggests that at some point, these patients may have been infected by the same strain from a different region. In addition, it is possible that they may have resided in the same house or city so that the same strain infected both of them through different routes of transmission. It is also possible that, in addition to biogeographic similarities, both share the same non-severe clinical outcomes. The different mechanisms underlying the pathogenesis of these strains can be explained by the genetic variations between them. 
The screening of a large number of samples would provide a better understanding of the possible variations in the $\operatorname{cag} A$ gene. Hence, a more comprehensive phylogeographic analysis is needed to elucidate the impact of genetic heterogeneity of $H$. pylori on dyspeptic patients in Brazil. Although this study involved a small sample number and partial gene sequences, this is the first Brazilian study that used partial $\operatorname{cag} A$ sequences from $H$. pylori to build a phylogenetic tree.

The present study has high scientific relevance, since information about the mechanisms involved in the parasite-host relationship is scarce in the researched population. Some limitations were observed in the study, such as the low sample size of patients with severe esogastroduodenal lesions and the partial sequencing of the $\operatorname{cag} A$ gene. Despite the limitations, the study opens perspectives for the development of personalized medicine in the Brazilian territory.

\section{CONCLUSION}

H. pylori infection is highly prevalent in patients with dyspepsia in central Brazil. The $\operatorname{cag} A$ oncogene was not considered to be a molecular marker of the severity of esogastroduodenal lesions. Through phylogenetic analyses, it was not possible to segregate strains from patients with severe and non-severe diseases. This study provides additional insight into the $\operatorname{cag} A$ profiles of the different strains of $H$. pylori and opens perspectives for studies with a larger sample size of esogastroduodenal disease patients as well as research that aims to assess the association between genetic variability and clinicopathological outcomes.

\section{ACKNOWLEDGMENTS}

We would like to thank the Genetics and Biodiversity Laboratory at the Federal University of Goiás. We also like to thank Editage for English language editing.

\section{Authors' contribution}

Oliveira AKS: responsible for the study, performed data collection, execution of molecular techniques, text writing and statistical analysis. Silva LLL: study collaborator, responsible for intellectual contribution, data analysis and execution of experiments. Miguel MP: responsible for assisting in histopathological analysis and assessments. Blanco AJV: collaboration in phylogenetic analyzes. Carneiro LC: intellectual contribution to the study. Barbosa MS: responsible for guidance in the execution of molecular techniques, manuscript correction, data analysis and intellectual contribution.

\section{Orcid}

Ana Karoline Silva Oliveira: 0000-0001-7576-5735.

Lucas Luiz de Lima Silva: 0000-0001-6510-4175.

Marina Pacheco Miguel: 0000-0002-6639-2452.

Angel José Vieira Blanco: 0000-0003-2712-7952.

Lilian Carla Carneiro: 0000-0003-4067-1506.

Mônica Santiago Barbosa: 0000-0001-6964-5219.

Oliveira AKS, Silva LLL, Miguel MP, Blanco AJV, Carneiro LC, Barbosa MS. Gene de virulência cagA de Helicobacter pylori e doenças esogastroduodenais severas: existe uma associação? Arq Gastroenterol. 2021;58(4):468-75.

RESUMO - Contexto - Helicobacter pylori coloniza aproximadamente metade da população humana mundial. A presença do microrganismo na mucosa gástrica está associada a um risco aumentado de adenocarcinoma gástrico, linfoma gástrico e úlcera péptica. No Brasil, a alta prevalência de infecção por H. pylori é um grave problema de saúde. Os fatores de virulência de H. pylori estão associados a risco aumentado de distúrbios gastrointestinais severos. O gene $\operatorname{cag} A$ codifica um antígeno associado à citotoxina $\mathrm{A}(\mathrm{CagA})$ que está envolvido na patogenicidade bacteriana. As cepas de $H$. pylori portadoras da ilha de patogenicidade cag ( $c a g$-PAI) estão significativamente associadas a desfechos clínicos severos e alterações histopatológicas. Objetivo - O presente estudo tem como objetivo investigar a prevalência do gene cag $A$ entre isolados de $H$. pylori de pacientes com diferentes desordens gástricas, bem como verificar sua associação com desfechos clínicos. Além disso, a análise filogenética foi realizada em cepas de $H$. pylori cag $A$-positivas de pacientes com doenças severas e não severas. Métodos - Amostras gástricas foram coletadas por meio de biópsia gástrica de 117 pacientes com diferentes doenças esogastroduodenais. O DNA foi extraído das amostras e utilizado para amplificar os fragmentos gênicos correspondentes aos genes RNA ribossomal $16 \mathrm{~S}$ e $\operatorname{cag} A$, através da reação em cadeia da polimerase. Os produtos da reação em cadeia da polimerase de amostras selecionadas positivas para cag $A$ foram sequenciados e as sequências foram alinhadas com sequências de referência do National Center for Biotechnology Information (NCBI) (Bethesda/EUA). As análises filogenéticas foram realizadas a partir do sequenciamento e construção da árvore filogenética. Resultados - $H$. pylori foi detectado em $65,9 \%$ (77/117) dos pacientes brasileiros com diferentes distúrbios gastroduodenais. No total, 80,5\% (62/77) das cepas foram cag $A$-positivas. As idades dos pacientes com cepas cagA-positivas (15 homens e 47 mulheres) variaram de 18 a 74 anos. As lesões foram categorizadas como não severas e severas de acordo com o laudo endoscópico e histopatológico. A lesão esogastroduodenal não severa mais prevalente foi gastrite $54 / 77(70,12 \%)$, seguida de esofagite 12/77 (15,58\%) e duodenite 12/77 (15,58\%). Em contraste, as lesões severas mais prevalentes foram atrofia 7/77 (9,09\%), seguida de metaplasia 3/77 (3,86\%) e adenocarcinoma gástrico 2/77 (2,59\%). As análises filogenéticas realizadas com as sequências parciais do gene cag $A$ obtidas de cepas locais foram agrupadas no mesmo clado. Nenhuma diferença na distribuição filogenética foi detectada entre doenças severas e não severas. Conclusão - O gene cag $A$ é altamente prevalente entre isolados de H. pylori de lesões gástricas em pacientes brasileiros. A presença do gene $\operatorname{cag} A$ não foi considerada um marcador de severidade das lesões esogastroduodenais no presente estudo. Este é o primeiro estudo a investigar a estrutura filogenética da população de cepas de H. pylori em uma capital brasileira. Esses resultados irão contribuir para o entendimento sobre o desfecho clínico da infecção por H. pylori.

Palavras-chave - Epidemiologia molecular; filogenia; fatores de virulência; gene bacteriano. 


\section{REFERENCES}

1. Warren JR, Marshall B. Unidentified Curved Bacilli on Gastric Epithelium in Active Chronic Gastritis. Lancet. 1983;321:1273-5.

2. Zamani M, Ebrahimtabar F, Zamani V, Miller WH, Alizadeh-Navaei R, ShokriShirvani J, et al. Systematic review with meta-analysis: the worldwide prevalence of Helicobacter pylori infection. Aliment Pharmacol Ther. 2018;47:868-76.

3. Zamani M, Vahedi A, Maghdouri Z, Shokri-Shirvani J. Role of food in environmental transmission of Helicobacter pylori. Casp J Intern Med. 2017;8:146-52.

4. Basílio ILD, Catão MDFC, Carvalho JDDS, Freire-Neto FP, Ferreira LC, Jerônimo SMB. Risk factors of Helicobacter pylori infection in an urban community in Northeast Brazil and the relationship between the infection and gastric diseases. Rev Soc Bras Med Trop. 2018;51:183-9.

5. Hooi JKY, Lai WY, Ng WK, Suen MMY, Underwood FE, Tanyingoh D, e al. Global Prevalence of Helicobacter pylori Infection: Systematic Review and Meta-Analysis. Gastroenterology. 2017;153:420-9.

6. Kamboj AK, Cotter TG, Oxentenko, Amy S. Oxentenko M. Helicobacter pylori: The Past, Present, and Future in Management. Mayo Clin Proc. 2017;92:599-604.

7. Cortes MCC, Yamakawa A, Casingal CR, Fajardo LSN, Juan MLG, De Guzman $\mathrm{BB}$, et al. Diversity of the cagA gene of Helicobacter pylori strains from patients with gastroduodenal diseases in the Philippines. FEMS Immunol Med Microbiol. 2010;60:90-7.

8. Junior LR, Miler C, Geocze S, Chehter L. Helicobacter pylori eradication does not influence gastroesophageal reflux disease: a prospective, parallel, randomized, open-label, controlled trial. Arq Gastroenterol. 2012;49:56-63.

9. Scida S, Russo M, Miraglia C, Leandro G, Franzoni L, Meschi T, et al. Relationship between Helicobacter pylori infection and GERD. Acta Biomed. 2018;89:40-3.

10. Liu L, Gao H, Wang H, Zhu K, Yu W, Zhang Y, et al. Comparison of esophageal function tests to investigate the effect of Helicobacter pylori infection on gastroesophageal reflux disease (GERD). Med Sci Monit. 2018;24:4791-7.

11. Araújo-Filho I, Brandão-neto J, Araújo L, Pinheiro M, Medeiros AC. Prevalence of Helicobacter pylori infection in advanced carcinoma. Arq Gastroenterol. 2006;43:288-92.

12. Zhang RG, Duan GC, Fan QT, Chen SY. Role of Helicobacter pylori infection in pathogenesis of gastric carcinoma. World J Gastrointest Pathophysiol. 2016;7:97.

13. Tomb JF, White O, Kerlavage AR, Clayton RA, Sutton GG, Fleischmann RD, et al. The complete genome sequence of the gastric pathogen Helicobacter pylori. Nature. 1997;388:539-47.

14. Pandya HB, Agravat HH, Patel JS. Prevalence of specific Helicobacter pylori CagA, VacA, IceA, UreC genotypes and its clinical relevance in the patients with acid-peptic diseases. J Clin Diagnostic Res. 2017;11:23-6.

15. Hatakeyama M. Oncogenic mechanisms of the Helicobacter pylori CagA protein. Nat Rev Cancer. 2004;4:688-94

16. Braga LLBC, Oliveira MAA, Gonçalves MHRB, Chaves FK, Benigno TGS Gomes AD, et al. CagA phosphorylation EPIYA-C motifs and the vacA i genotype in Helicobacter pylori strains of asymptomatic children from a high-risk gastric cancer area in northeastern Brazil. Mem Inst Oswaldo Cruz. 2014;109:1045-9.

17. Tegtmeyer N, Wessler S, Necchi V, Rohde M, Harrer A, Rau TT, et al. Helicobacter pylori employs a unique basolateral type IV secretion mechanism for CagA delivery. Cell Host Microbe. 2017;22:552-60.

18. Nishizawa T, Suzuki H. Gastric carcinogenesis and underlying molecular mechanisms: Helicobacter pylori and novel targeted therapy. Biomed Res Int. 2014;2015.

19. Miftahussurur M, Yamaoka Y. Helicobacter pylori virulence genes and host genetic polymorphisms as risk factors for peptic ulcer disease. Expert Rev Gastroenterol Hepatol. 2015;9:1535-47.

20. Lind J, Backert S, Pfleiderer K, Berg DE, Yamaoka Y, Sticht H, et al. Systematic analysis of phosphotyrosine antibodies recognizing single phosphorylated EPIYA-motifs in CagA of western-type Helicobacter pylori strains. PLoS One. 2014;9:14-8

21. Rugge M. Gastric cancer risk in patients with Helicobacter pylori infection and following its eradication. Gastroenterol Clin North Am. 2015;44:609-24.

22. Matos JI, Sousa HAC, Marcos-Pinto R, Dinis-Ribeiro M. Helicobacter pylori CagA and VacA genotypes and gastric phenotype: A meta-analysis. Eur J Gastroenterol Hepatol. 2013;25:1431-41.

23. Coelho LGV, Marinho JR, Genta R, Ribeiro LT, Passos M do CF, Zaterka S, et al. IVth Brazilian consensus conference on Helicobacter pylori infection. Arq Gastroenterol. 2018;55:97-121.
24. Giemsa G. A simplification and perfection of my methylene azure-methylene blue-eosin staining method for the political purpose of Romanowsky-Nochteschen chromatin staining. Zentralbl Bakteriol. 1904;308-11.

25. Stolte M, Meining A. The Updated Sydney System: Classification and grading of gastritis as the basis of diagnosis and treatment. Can J Gastroenterol. 2001; 15:591-8.

26. Paredes-Osses E, Sáez K, Sanhueza E, Hebel S, González C, Briceño C, et al. Association between $\operatorname{cag} A$, vacAi, and dupA genes of Helicobacter pylori and gastroduodenal pathologies in Chilean patients. Folia Microbiol (Praha). 2017;62:437-44

27. Bellolio E, Riquelme I, Riffo-Campos AL, Rueda C, Ferreccio C, Villaseca M, et al. Assessment of gastritis and gastric cancer risk in the Chilean population using the OLGA system. Pathol Oncol Res. 2019;25:1135-42.

28. Luscenti RS, Gatti LL. Molecular diagnosis of Helicobacter pylori infection in the gastric mucosal. Rev Para Med. 2008;22:21-6.

29. Dadashzadeh K, Peppelenbosch MP, Adamu AI. Helicobacter pylori pathogenicity factors related to gastric cancer. Can J Gastroenterol Hepatol. 2017;2017:1-6.

30. Sanger F, Coulson AR, Friedmann T, Air GM, Barrell BG, Brown NL, et al. The nucleotide sequence of bacteriophage $\phi X 174$. J Mol Biol. 1978;125:225-46.

31. Kumar S, Stecher G, Li M, Knyaz C, Tamura K. MEGA X: Molecular evolutionary genetics analysis across computing platforms. Mol Biol Evol. 2018; 35:1547-9.

32. Eusebi LH, Zagari RM, Bazzoli F. Epidemiology of Helicobacter pylori infection. Helicobacter. 2014;19(S1):1-5

33. Leja M, Grinberga-Derica I, Bilgilier C, Steininger C. Epidemiology of Helicobacter pylori infection. Helicobacter. 2019;24(S1):2-6.

34. Román-Román A, Martínez-Santos VI, Castañón-Sánchez CA, Albañil-Muñoz AJ, González-Mendoza P, Soto-Flores DG, et al. CagL polymorphisms D58/K59 are predominant in Helicobacter pylori strains isolated from mexican patients with chronic gastritis. Gut Pathog. 2019;11:1-11.

35. Abu-Taleb AMF, Abdelattef RS, Abdel-Hady AA, Omran FH, El-Korashi LA, Abdel-Aziz El-Hady H, et al. Prevalence of Helicobacter pylori cag A and ice $A$ genes and their association with gastrointestinal diseases. Int $\mathbf{J}$ Microbiol. $2018 ; 2018$.

36. Ramis IB, Fonseca TL, de Moraes EP, Fernandes MS, Mendoza-Sassi R, Rodrigues $\mathrm{O}$, et al. Molecular Basis of pathogenicity in Helicobacter pylori clinical isolates. J Clin Microbiol. 2010;48:3776-8.

37. Cavalcante MQ, Silva CI, Braga-Neto MB, Fialho AB, Nunes Fialho A, Barbosa AM, et al. Helicobacter pylori vacA and cagA genotypes in patients from northeastern Brazil with upper gastrointestinal diseases. Mem Inst Oswaldo Cruz. 2012;107:561-3.

38. Oliveira AG, Santos A, Guerra JB, Rocha GA, Rocha AM, Oliveira CA, et al. babA2- and cagA-positive Helicobacter pylori strains are associated with duodenal ulcer and gastric carcinoma in Brazil. J Clin Microbiol. 2003;41:3964-6.

39. Estimated age-standardized incidence rates (World) in 2018, all cancers, both sexes, all ages [Internet]. Lyon, France: International Agency for Research on Cancer; 2018 [cited 2020 Mar 1]. Available from: http://gco.iarc.fr/today.

40. Gomes LI, Rocha GA, Rocha AMC, Soares TF, Oliveira CA, Bittencourt PFS, et al. Lack of association between Helicobacter pylori infection with dupA-positive strains and gastroduodenal diseases in Brazilian patients. Int J Med Microbiol. 2008;298:223-30.

41. Backert S, Tegtmeyer N. Type iv secretion and signal transduction of Helicobacter pylori cag $A$ through interactions with host cell receptors. Toxins (Basel). 2017;9:115.

42. Ferro A, Morais S, Pelucchi C, Dierssen-Sotos T, Martín V, López-Carrillo L, et al. Sex differences in the prevalence of Helicobacter pylori infection: An individual participant data pooled analysis (StoP Project). Eur J Gastroenterol Hepatol. 2019;31:593-8.

43. Levorato CD, de Mello LM, da Silva AS, Nunes AA. Factors associated with the demand for health services from a gender-relational perspective. Cienc e Saude Coletiva. 2014;19:1263-74

44. Ibrahim A, Morais S, Ferro A, Lunet N, Peleteiro B. Sex-differences in the prevalence of Helicobacter pylori infection in pediatric and adult populations: Systematic review and meta-analysis of 244 studies. Dig Liver Dis. 2017; 49:742-9 